\title{
Geogratia
}

Malaysian Tournal of Society and Space

\section{Kecenderungan penggunaan perkhidmatan penghantaran makanan secara dalam talian di Pulau Pinang}

\author{
Jannatul 'Agilah Said, Narimah Samat \\ GeoInformatic Unit, Bahagian Geografi, Pusat Pengajian Ilmu Kemanusiaan \\ Universiti Sains Malaysia \\ Correspondence: Narimah Samat (email: narimah@usm.my)
}

Received: 12 December 2020; Accepted: 18 June 2021; Published: 27 August 2021

\begin{abstract}
Abstrak
Kesesakan lalu lintas, ruangan letak kenderaan terhad, jadual kerja yang padat, dan perubahan gaya hidup dari kesan langsung proses perbandaran menyebabkan penduduk cenderung menggunakan perkhidmatan penghantaran makanan (PPM) secara dalam talian. Walaupun PPM digunakan dengan meluas di Malaysia, masih tidak banyak kajian dijalankan dalam mengenal pasti faktor kecenderungan penduduk menggunakan perkhidmatan ini. Tujuan kertas kerja ini adalah mengenalpasti faktor kecenderungan penduduk mendapatkan makanan menggunakan PPM secara dalam talian dan mengkaji perubahan gaya hidup penduduk di bandar. Kajian ini dijalankan menggunakan kaedah kuantitatif melibatkan 110 responden yang menetap di Pulau Pinang. Kajian ini juga memberikan perhatian kepada responden yang pernah menggunakan perkhidmatan ini. Hasil analisis menggunakan skor min mendapati empat faktor utama penentu kecenderungan penduduk terhadap PPM mendapatkan makanan iaitu lokasi, kualiti perkhidmatan yang ditawarkan, perubahan gaya hidup dan penularan pandemik COVID-19. Namun ruang tempat kereta yang terhad adalah menjadi sebab utama pemilihan PPM. Kajian juga mendapati responden cenderung memilih perkhidmatan Foodpanda kerana ianya mudah dan cepat. Hasil kajian dapat menyumbang kepada agensi PPM berkaitan dalam merangka dan merancang strategi dengan lebih menyeluruh bagi meningkatkan perkhidmatan PPM dalam kalangan penduduk bandar.
\end{abstract}

Kata kunci: COVID-19, gaya hidup, kualiti, lokasi, perbandaran, PPM

\section{The Trend in Using Online Food Delivery Services in Pulau Pinang}

\begin{abstract}
Traffic congestion, limited parking spaces, tight work schedules, and lifestyle changes are among the direct impact of urbanization process which caused the tendency of residents to use online food
\end{abstract}


delivery services (PPM). Although PPM has widely been used in Malaysia, there are still limited studies conducted that identify the factors influencing the tendency of its usage. The purpose of this article is to identify the factors of the residents' tendency to obtain food using PPM and study the lifestyle changes among urban population. This study was conducted using a quantitative approach involving 110 respondents living in Pulau Pinang that had previously used PPM. Based on mean score analysis, the four main factors determining the tendency of PPM usage were location, quality of services offered, lifestyle changes and the spread of the COVID-19 pandemic. However, limited parking space was the main reason for using PPM. Among the PPM service providers, Foodpanda was frequently used due to ease of use and fast delivery. The findings can benefit PPM service providers in planning and formulating effective strategies toward increasing PPM usage among urban residents

Keyword: COVID-19, lifestyle, quality, location, urbanization, PPM

\section{Pengenalan}

Kepesatan peningkatan penduduk bandar telah membawa kepada kesibukan dan kesesakan lalu lintas sekaligus memberikan tekanan kepada penduduk bagi meneruskan kehidupan seharian (Rostam et al., 2017; Aladağ, 2019). Pada tahun 1950, populasi penduduk dunia adalah seramai 2.54 juta menetap di kawasan bandar (UN, 2008) dan jumlah ini dianggarkan terus meningkat dengan 60 peratus penduduk menghuni kawasan bandar bagi tahun 2030 (UN, 2019).

Hasil tinjauan bagi negara Asia Tenggara iaitu Malaysia mencatatkan jumlah penduduk seramai 32,365,999 pada tahun 2019 dan terus meningkat kepada 32,619,400 pada tahun 2020 dengan peratus penduduk bandar melebihi 76.6\% (Jabatan Perangkaan Malaysia, 2020: Mactotrends, 2021). Peningkatan penduduk yang drastik di bandar telah menyumbang kepada masalah kesibukan dan kesesakan lalu lintas di kawasan tersebut. Walau bagaimanapun kepesatan pembangunan bandar turut membawa kesan positif. Contohnya, ianya membawa kepada perkembangan dalam perkhidmatan elektronik (Laddha, 2019) iaitu bidang ICT telah membantu memudahkan kehidupan seharian.

Selari dengan perkembangan ICT, industri makanan dan minuman telah melakukan anjakan baru dengan menawarkan kaedah PPM secara dalam talian (Chai \& Yat, 2019). Kaedah baharu ini menjadi pilihan pengguna kerana maklumat barangan telah tersedia dalam aplikasi serta memudahkan proses interaksi antara penjual dan pembeli tanpa had masa dan sempadan geografi (Kimes, 2011; Ledimo \& Martins, 2015). Walaupun PPM telah digunakan dengan meluas, kajian mengenai faktor kecenderungan penduduk terhadap perkhidmatan ini masih kurang dijalankan. Oleh hal yang demikian, kertas kerja ini bertujuan mengenalpasti faktor kecenderungan penduduk mendapatkan makanan menggunakan PPM secara dalam talian dan mengkaji perubahan gaya hidup penduduk di bandar.

\section{Latar belakang kajian}

\section{Perkhidmatan penghantaran makanan (PPM)}

PPM merupakan perniagaan yang berkembang pesat di negara-negara membangun seperti Malaysia. Menurut Statita.com (2020), di Malaysia perniagaan ini membawa hasil sebanyak 317 
juta pada tahun 2017 dan meningkat kepada 605.8 juta pada tahun 2019. Perniagaan ini dijangka mencapai hasil 881.6 juta pada tahun 2020 dengan pengguna melebihi 6.9 juta. Perniagaan ini telah berkembang pesat disebabkan permintaan yang tinggi dalam kalangan masyarakat bandar.

PPM juga semakin diterima memandangkan ianya mudah, menjimatkan masa dan kepelbagaian makanan yang boleh ditempah (Tan, 2019). Terdapat dua jenis perniagaan yang menawarkan perniagaan PPM iaitu premis perniagaan menawarkan PPM dan PPM sebagai perantara antara restoran dan pengguna. PPM daripada premis perniagaan makanan contohnya melibatkan rantaian premis perniagaan makanan segera seperti Pizza Hut, McDonalds, Domino's Pizza dan Kentucky Fried Chicken (KFC) (Li, Mirosa \& Bremer, 2020).

Manakala, PPM sebagai pengantara pula melibatkan PPM yang menjadi perantaraan melakukan penghantaran daripada pelbagai restoran seperti Foodpanda dan Grab Food (Yeo et al., 2017). Rentetan daripada itu, tinjauan literatur mendapati terdapat empat faktor yang menjadi penyebab kepada kecenderungan pengguna mendapatkan makanan dalam kalangan penduduk yang tinggal di bandar. Faktor ini termasuklah lokasi, kualiti perkhidmatan yang ditawarkan, perubahan gaya hidup dan penularan pandemik COVID-19. Selain itu, Sakaran et al., (2020) menjelaskan isu geografi dalam aspek luaran dan isu agensi perkhidmatan bagi aspek dalaman mempengaruhi perubahan pergerakan penduduk seperti ditunjukkan di dalam Rajah 1.

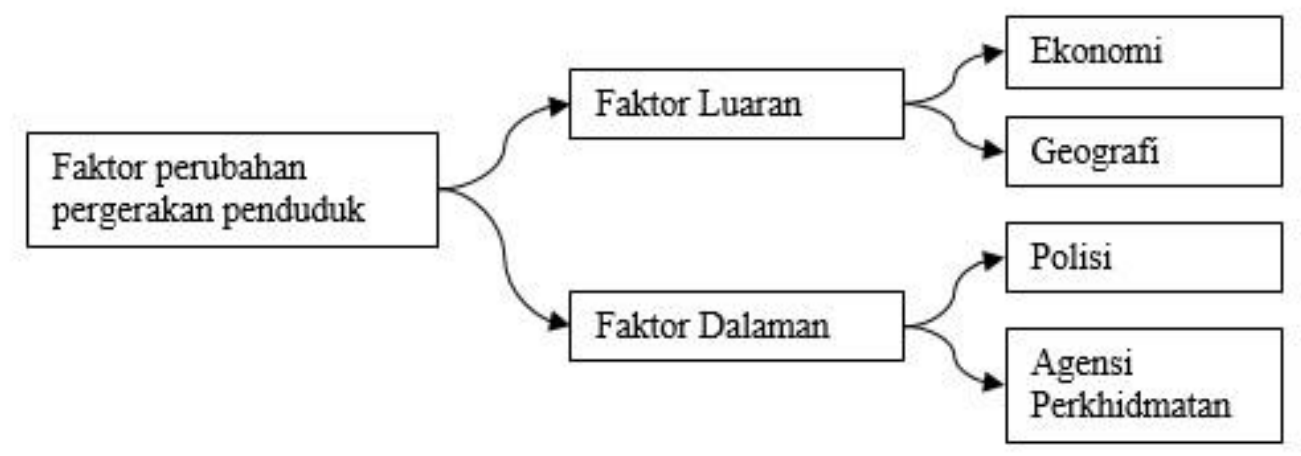

Sumber: Ubahsuai daripada Taylor \& Fink, 2003; Harifah, 2015 dan Sakaran et al., 2020

Rajah 1. Faktor perubahan pergerakan penduduk

\section{Faktor lokasi}

Menerusi kajian yang telah dijalankan oleh Taylor dan Fink (2003), Harifah (2015) dan Sakaran et al., (2020) mod pergerakan berubah disebabkan faktor luaran dan dalaman yang merangkumi faktor ekonomi, geografi, polisi dan agensi perkhidmatan. Antara faktor yang diberikan perhatian terhadap kecenderungan penggunaan PPM adalah faktor luaran merangkumi isu geografi kawasan tersebut. Isu geografi ini dikaitkan dengan lokasi premis perniagaan yang kurang strategik dengan adanya ruangan letak kereta terhad dan kesesakan lalu lintas. Situasi ini disebabkan oleh lokasi premis perniagaan yang dibina, contohnya kedudukan lokasi premis perniagaan berdekatan dengan kawasan perumahan, kawasan lot komersial, kolej, pusat hiburan dan kawasan gerai yang terdapat di tepi jalan (See-Kwong et al., 2017).

Bagi mengelakkan situasi tersebut, penduduk memilih menggunakan PPM bagi mendapatkan makanan dengan segera dan cepat tanpa keluar ke premis perniagaan tersebut. Selain daripada faktor kedekatan lokasi tersebut, PPM ini turut mudah digunakan disebabkan ICT yang 
membantu pengguna mengetahui lokasi pilihan menggunakan Global Positioning System (GPS) sama ada pada jarak dekat mahupun jauh (Parsa et al., 2011; Nabila et al., 2018). Bukan itu sahaja, pengguna dapat mengetahui jarak lokasi premis perniagaan dan keberadaan agen penghantaran semasa penghantaran makanan dilakukan (Ilham, 2018).

Namun, PPM mempunyai cabaran dalam rangkaian dan capaian internet yang disebabkan oleh faktor fizikal lokasi. Cabaran tersebut perlu diterima oleh pihak agen penghantaran ataupun premis perniagaan bagi mengekalkan tahap kepuasan pengguna PPM (Chai \& Yat, 2019). Secara keseluruhannya, faktor luaran dibincangkan ini secara tidak langsung memberikan impak kepada kualiti perkhidmatan yang ditawarkan kepada pengguna.

\section{Kualiti perkhidmatan yang ditawarkan}

Menurut kajian yang dijalankan oleh Ilham (2018) terdapat lima pengukuran yang terdapat dalam kualiti perkhidmatan bagi meningkatkan kepuasan dan kesetiaan pengguna terhadap PPM. Antaranya ialah keselamatan, komunikasi, kebolehpercayaan, tindak balas dan penghantaran. Malah, ketepatan maklumat yang diberikan mempengaruhi tahap kepuasan pengguna terhadap kualiti yang ditawarkan oleh agensi PPM dan pengusaha premis perniagaan (Flavian \& Guinaliu, 2006). Kemudahan dan ketepatan penyampaian maklumat menerusi aplikasi PPM menyebabkan PPM ini diterima oleh penduduk. Penggunaan teknologi aplikasi secara dalam talian bukan lagi perkara baharu dalam teknologi berkomputer (Yeo et al., 2017).

Penerimaan teknologi tersebut yang cepat kerana tanggapan penduduk terhadap teknologi mempunyai kebergunaan dan juga mudah digunakan di mana sahaja (Davis et al., 1989). Kebergunaan teknologi ini melibatkan kepercayaan pengguna terhadap teknologi tersebut, justeru aplikasi PPM digunakan kerana penduduk merasakan sistem teknologi atau aplikasi tersebut boleh dipercayai (Davis et al., 1989; Nabila et al., 2018). Tidak dinafikan lagi bahawa aplikasi PPM ini mudah digunakan oleh penduduk kerana fungsi penggunaan yang mudah difahami dan dipelajari serta ketersampaian maklumat yang disalurkan kepada pengguna yang jelas dan tepat menjamin kualiti perkhidmatan ditawarkan (Chai \& Yat, 2019).

\section{Perubahan gaya hidup penduduk}

Penggunaan PPM ini bukan sahaja disebabkan faktor lakosi-lokasi dan kualiti perkhidmatan yang ditawarkan, malah perubahan gaya hidup penduduk turut mempengaruhi kecenderungan menggunakan PPM ini (Zulkarnain et al., 2015). Perniagaan PPM bukan lagi perkara baharu di negara maju seperti Amerika (Annaraud \& Berezina, 2020; Keeble et al., 2020). Namun, bagi negara membangun PPM ini adalah normal baharu yang diperkenalkan bagi kemudahan mendapatkan makanan dengan segera (Chai \& Yat, 2019).

Kemudahan PPM ini telah mengubah naratif gaya hidup penduduk mendapatkan makanan dengan memesan menggunakan aplikasi PPM. PPM ini semakin meningkat dalam kalangan penduduk disebabkan oleh peningkatan pengguna telefon pintar dengan kadar penebusan jalur lebar yang tinggi (Cho et al., 2019). Di Malaysia, statistik menunjukkan seramai 17.9 juta penduduk telah mengakses internet menerusi telefon pintar pada tahun 2016. Jumlah pengguna ini dianggarkan meningkat pada tahun 2020 iaitu seramai 21.1 juta orang (Chai \& Yat, 2019) dengan kadar penebusan jalur lebar isi rumah mencapai paras 81.8 peratus pada tahun 2017 (Nazurah Ngah et al., 2017). Hal ini kerana kemudahan capaian internet yang tinggi membolehkan penduduk mengakses kepada perkhidmatan ini. 
Menurut SKMM (2020), di Malaysia juga telah mencatatkan peratus pengguna internet mudah alih iaitu 88.7 juta pada tahun 2020 meningkat sebanyak 1.3 peratus daripada 87.4 peratus pada tahun 2018 dengan peratus pengguna telefon bimbit iaitu 98.7 peratus. Oleh itu, penyediaan kemudahan ini mendorong kecenderungan penduduk terhadap PPM dalam mendapatkan makanan dengan segera. Jadi hal ini secara tidak langsung menggunakan PPM menunjukkan perubahan gaya hidup ke arah lebih digital.

\section{Penularan pandemik Koronavirus (COVID-19)}

Perniagaan PPM telah diperkenalkan di Malaysia sekitar tahun 2012 (Pigatto et al., 2017) seringkali digunakan oleh penduduk yang tinggal di bandar besar seperti Kuala Lumpur, Lembah Klang, Pulau Pinang dan Johor (Chai \& Yat, 2019). Salah satu peningkatan kecenderungan menggunakan PPM ini disebabkan penularan virus COVID-19 yang diistiharkan sebagai pandemik pada 11 March 2020 dan pelaksanaan perintah kawalan pergerakan (PKP) (Nicola et al., 2020). Perniagaan PPM ini mengalami permintaan tinggi yang drastik daripada penduduk bagi mendapatkan makanan dengan segera dan selamat (Liza Mohtar \& Nurul Riduan, 2020).

Pelaksanaan PKP telah melonjakkan lebih 30 peratus permintaan PPM oleh penduduk terutamanya di bandar. Penggunaan PPM ini adalah sebagai langkah menjaga keselamatan daripada dijangkiti penyakit tersebut. Kebimbangan dan ketidakselesaan untuk keluar mendapatkan makanan menyebabkan PPM menjadi pilihan kepada penduduk (BERNAMA, 2020). Selain itu, penggunaan PPM ini adalah untuk mengelakkan kesesakan di sesuatu lokasi. PPM juga digemari kerana premis perniagaan turut menghadkan jumlah pelanggan di dalam premis (Nicola et al., 2020). Oleh itu, bagi mengimbangi keperluan pertumbuhan ekonomi serta memastikan rantaian penyebaran COVID-19 dihentikan maka penggunaan PPM ini adalah sangat penting kepada penduduk (Suhaimi Ab Rahman, 2020).

\section{Perkaitan penggunaan ICT}

Pengukuhan hubungan antara lokasi dengan penggunaan ICT menyebabkan kemunculan pergerakan dalam talian atau mobiliti maya (virtual mobility) (Daniel et al., 2018) sehingga konsep tele-hubungan bandar (Urban Land Tele-connection (ULT)) diperkenalkan Seto et al., (2012). ULT ini merupakan konseptual yang melibatkan proses menghubungkan penggunaan tanah, perbandaran dan tempat melalui proses-proses tertentu. Berikutan proses tersebut, berlaku proses perubahan di kawasan bukan bandar yang mempengaruhi kawasan bandar. Salah satu asas perubahan dapat dilihat adalah telekomunikasi bandar membangunkan kawasan bukan bandar, ULT ini juga melibatkan hubungan aliran di antara pengguna, barang dan perkhidmatan, ekonomi, dan proses perubahan guna tanah mendorong ke arah perbandaran (Seto et al., 2012).

Kemunculan konsep ini akibat pembangunan bandar yang pesat berlaku seiring peningkatan teknologi pada suatu kawasan yang melibatkan hubungkait sambungan jalur lebar kepada penduduk (Güneralp et al., 2012). Pengukuhan hubungan lokasi dengan sambungan jalur lebar menyebabkan pergerakan secara dalam talian berlaku. Salah satu kemunculan pergerakan secara dalam talian yang dikenalpasti adalah pergerakan pengguna yang menggunakan aplikasi PPM (Daniel et al., 2018). Pergerakan ini hanya berlaku bagi konteks pengguna PPM sahaja kerana pengguna memesan makanan menggunakan aplikasi PPM tanpa perlu bergerak ke lokasi premis perniagaan tersebut. Oleh itu, konsep ULT ini penting diteliti melibatkan perkaitan proses dengan tempat yang berlaku akibat perbandaran dan perubahan guna tanah yang diterokai (Güneralp et al., 
2012). Dalam memahami konsep ini dalam konteks Malaysia, kajian ini bertujuan mengkaji kecenderungan PPM di Pulau Pinang.

\section{Metodologi dan kawasan kajian}

Kajian ini adalah mengenalpasti faktor kecenderungan penduduk mendapatkan makanan menggunakan PPM secara dalam talian dan mengkaji perubahan gaya hidup penduduk di bandar. Kajian ini menggunakan data sumber primer dan sekunder dalam pengumpulan maklumat dengan lebih terperinci. Pendekatan kuantitatif digunakan bagi mengukur dan melihat hasil impak pembolehubah. Pengumpulan data menggunakan tinjauan borang soal selidik dalam talian melalui Google Docs disebabkan penularan pandemik COVID-19. Kajian ini menggunakan borang soal selidik secara dalam talian yang diedarkan kepada responden yang tinggal di Pulau Pinang menerusi media sosial seperti Whatsapp, Facebook, Intagram dan emel antara 30 Mac 2020 sehingga 12 April 2020. Responden dipilih mestilah pengguna yang pernah menggunakan PPM.

Kaedah persampelan bertujuan telah digunakan dalam kajian ini iaitu seramai 110 orang responden yang terdiri dalam kalangan penduduk Pulau Pinang. Borang soal selidik ini menggunakan skala lima likert iaitu "sangat tidak setuju", "tidak setuju", "neutral", "setuju" dan "sangat setuju" untuk mendapatkan persepsi penduduk terhadap penggunaan PPM di Pulau Pinang. Setelah pengumpulan maklumat dilakukan, data yang diperoleh, diproses dan dianalisis menggunakan Statistical Package for the Social Sciences (SPSS) versi 26 dan analisis statistik deskriptif serta analisis tabulasi silang telah dijalankan bagi menganalisis kecenderungan responden dalam menggunakan PPM. Selain itu, analisis menggunakan skor min iaitu skor min 1.00 hingga 2.33 menunjukkan nilai min pada tahap yang rendah, sementara skor min 2.34 hingga 3.66 pada tahap sederhana dan akhir sekali skor min 3.67 hingga 5.00 pada tahap yang tinggi (Suan 2003).

Kajian ini dijalankan di Pulau Pinang yang memiliki keluasan sebanyak 1,031 km persegi dan terdiri daripada sebahagian pulau dan Seberang Perai yang terletak pada garis lintang latitud $5^{\circ} 8^{\prime} \mathrm{U}$ hingga $5^{\circ} 35^{\prime} \mathrm{U}$ dan longitud $100^{\circ} 8^{\prime} \mathrm{B}$ hingga $100^{\circ} 32^{\prime} \mathrm{U}$ (rujuk Rajah 2). Kajian dijalankan di Pulau Pinang, menurut laporan Rancangan Struktur Negeri Pulau Pinang 2030 (2018) menjelaskan bahawa Pulau Pinang mengalami pembangunan yang pesat menjadikan negeri ini sebagai "Silicon Valley of The East" (RSNPP 2030, 2018). Negeri ini di antara negeri yang mengalami kepesatan perbandaran iaitu sebanyak 79.5 peratus selepas Wilayah Persekutuan Kuala Lumpur dan Selangor pada tahun 2000. Kepadatan penduduk negeri ini di antara yang tertinggi di Malaysia iaitu 1,684 orang bagi setiap kilometer persegi dan juga memiliki KDNK per kapita tertinggi berbanding negeri lain. Data yang dikeluarkan oleh Jabatan Perangkaan Malaysia menunjukkan kepadatan penduduk Pulau Pinang pada tahun 2010 adalah sebanyak 1.5 juta orang dan peningkatan jumlah kepadatan pada tahun 2018 iaitu 1.7 juta orang (JPM, 2018). 


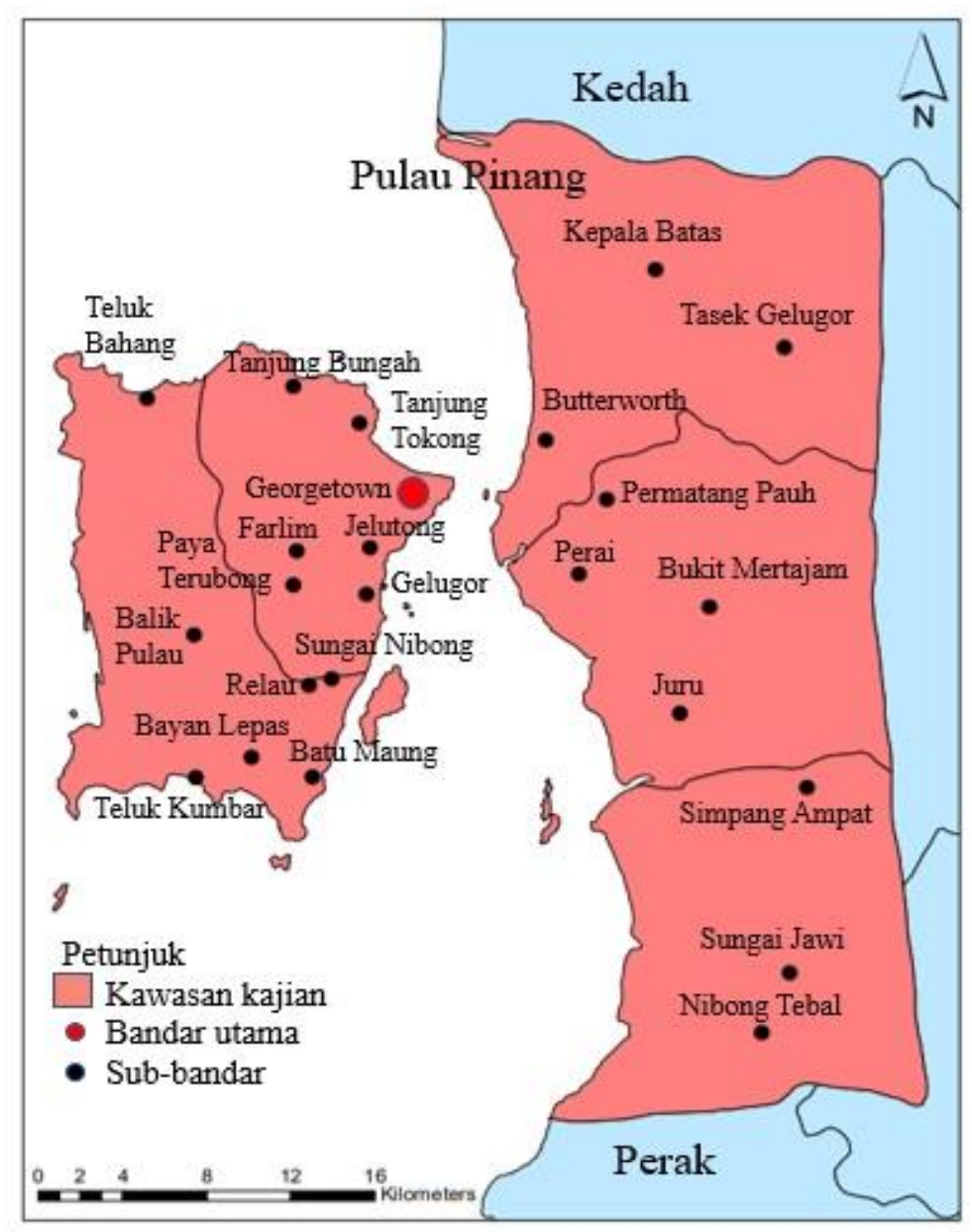

Rajah 2. Kawasan kajian - Pulau Pinang

Selain itu, laporan RSNPP 2030 menerangkan bahawa kepesatan pembangunan negeri ini dipengaruhi oleh peningkatan evolusi yang dijalankan iaitu 2.0 dan 3.0, malah sasaran bagi tahun 2030 industri Pulau Pinang mencapai tahap 4.0 (RSNPP 2030, 2018). Pemilihan kawasan ini juga kerana ianya berada di dalam Koridor Ekonomi Wilayah Utara (NCER) yang dirancang untuk berperanan sebagai pusat wilayah yang menjadi pemacu pertumbuhan ekonomi negara terutamanya di wilayah Semenanjung Malaysia (Yusof, Lazim, \& Dawood, 2013). Selain itu, negeri ini telah menunjukkan kadar penebusan kadar jalur lebar yang keempat tertinggi di Malaysia iaitu 105.1 peratus pada tahun 2016 (SKMM, 2016). Bertetapan dengan sifat bandar yang ditunjukkan maka negeri ini dipilih bagi melihat penggunaan PPM dalam kalangan penduduk (Chai, \& Yat 2019).

\section{Hasil dan perbincangan}

\section{Profil demografi responden}

Bagi mengkaji kecenderungan penduduk kepada PPM, kajian ini mengumpulkan data daripada 110 responden menggunakan soal selidik dalam talian. Profil responden adalah seperti Jadual 1. 
Responden lelaki seramai 36 orang iaitu 32.7 peratus dan perempuan seramai 74 orang iaitu 67.3 peratus. Umur responden kajian ini menunjukkan peratusan tinggi adalah golongan muda dalam linkungan umur 21-30 tahun sebanyak 63.6 peratus diikuti golongan berumur 31-40 tahun iaitu sebanyak 24.5 peratus. Umur dalam golongan belajar atau masih muda kerana soal selidik dijalankan dalam talian. Hal ini dikatakan demikian kerana, capaian kepada golongan muda adalah lebih baik. Majoriti responden yang menyertai kajian ini mempunyai tahap kelulusan yang tinggi dengan peratusan sebanyak 66.4 peratus dan diikuti oleh taraf pendidikan di peringkat STPM/Diploma sebanyak 23.6 peratus. Jumlah tertinggi yang mengikuti kajian ini adalah golongan bekerja iaitu sebanyak 53.9 peratus dan diikuti oleh pelajar iaitu 39.1 peratus. Kajian ini mendapati responden menggunakan PPM ini adalah golongan kategori pendapatan RM 3000 ke bawah iaitu sebanyak 35.5 peratus dan tidak berkenaan (tiada pendapatan seperti pelajar) iaitu 52.7 peratus.

Jadual 1. Profil demografi penduduk di Pulau Pinang

\begin{tabular}{llcc}
\hline Demografi & Profil Responden & Kekerapan & Peratusan (\%) \\
\hline Jantina & Lelaki & 36 & 32.7 \\
& Perempuan & 74 & 67.3 \\
\hline Umur & 20 tahun ke bawah & 6 & 5.5 \\
& 21-30 tahun & 70 & 63.6 \\
& $31-40$ tahun & 27 & 24.5 \\
& 41-50 tahun & 5 & 4.5 \\
& 51 tahun ke atas & 2 & 1.8 \\
\hline Kaum & Melayu & 101 & 91.8 \\
& Cina & 5 & 4.5 \\
& India & 0 & 0.0 \\
& Lain-lain & 4 & 3.6 \\
\hline Taraf pendidikan & Pendidikan tidak formal & 1 & 1.0 \\
& Sekolah Rendah & 0 & 0.0 \\
& Sekolah Menengah & 10 & 9.1 \\
& STPM/Diploma & 26 & 23.6 \\
& Pengajian Tinggi & 73 & 66.4 \\
\hline Status pekerjaan & Bekerja & 59 & 53.6 \\
& Sedang mencari kerja & 7 & 6.4 \\
& Suri rumah & 1 & 1.0 \\
& Pelajar & 43 & 39.1 \\
\hline Pendapatan & RM 3000 ke bawah & 39 & 35.5 \\
& RM 3001- RM 6000 & 9 & 8.2 \\
& RM 6001- RM 13000 & 2 & 1.8 \\
& RM 13001 ke atas & 2 & 1.8 \\
& Tidak berkenaan & 58 & 52.7 \\
\hline
\end{tabular}

Sumber: Kajian lapangan, 2020

\section{Faktor kecenderungan penggunaan PPM}

Seterusnya, analisis ini dilakukan bagi mengenalpasti faktor utama kecenderungan penduduk menggunakan PPM. Berdasarkan kepada Jadual 2 menunjukkan faktor lokasi mempunyai nilai min keseluruhan yang tinggi iaitu 4.24 berbanding faktor kualiti perkhidmatan yang ditawarkan iaitu 3.77, perubahan gaya hidup iaitu 4.23 dan penularan pandemik covid 19 iaitu 3.61. Dalam konteks kajian ini, lokasi antara elemen penting kecenderungan penduduk menggunakan PPM ini. 
Hal ini jelaslah menunjukkan bahawa faktor lokasi juga perlu dititikberatkan oleh pihak berkepentingan yang terlibat (Chai \& Yat, 2019).

Jadual 2. Faktor kecenderungan penduduk terhadap PPM

\begin{tabular}{llcc}
\hline Faktor & \multicolumn{1}{c}{ Item } & Min & $\begin{array}{c}\text { Min } \\
\text { keseluruhan }\end{array}$ \\
\hline Lokasi & Kawasan yang berdekatan & 4.23 & \\
& Kos pengangkutan berkurang & 4.10 & 4.24 \\
& Keadaan jalan raya & 4.32 & \\
& Ruangan tempat letak kenderaan & 4.34 & \\
\hline Kualiti & Khidmat pelanggan & 3.95 & \\
perkhidmatan yang & Komunikasi dengan pelanggan & 4.05 & 3.77 \\
ditawarkan & Caj penghantaran & 3.47 & \\
& Harga berpatutan & 3.60 & \\
\hline Perubahan gaya & Teknologi (lokasi mudah akses- & 3.98 & \\
hidup & GPS) & 3.93 & \multirow{2}{*}{4.23} \\
& Kemudahan internet & 4.40 & \\
& Kemudahan telefon pintar & 4.61 & \\
\hline Penularan & Aplikasi PPM mudah digunakan & 3.61 & 3.61 \\
pandemik Covid-19 & Perintah Kawalan Pergerakan & & \\
\hline Sumber: Kajian lapangan, 2020 & &
\end{tabular}

Dalam konteks kajian ini melihat faktor luaran iaitu faktor lokasi yang menjadi penyebab kecenderungan menggunakan PPM meningkat. Dapatan kajian ini menunjukkan pengukuran lokasi merangkumi kawasan yang berdekatan, kos pengangkutan berkurang, keadaan jalan raya dan ruangan tempat letak kenderaan. Antara skor min pada tahap tertinggi adalah ruangan tempat letak kenderaan iaitu 4.34 berbanding kos pengangkutan berkurang iaitu 4.10, kawasan yang berdekatan iaitu 4.23 dan keadaan jalan raya (seperti kesesakan berlaku) iaitu 4.32. Dapatan kajian ini bertetapan dengan kajian yang dijalankan oleh Chai dan Yat (2019) menjelaskan ruangan tempat letak kenderaan yang terhad mempengaruhi penduduk memesan makanan menggunakan PPM. Ruangan tempat letak kenderaan terhad disebabkan pembangunan yang berlaku di suatu kawasan dengan padat seperti kawasan pasar raya dan juga kedudukan tempat makan di tepi jalan raya (Tzenget et al., 2002; Timor \& Sipahi 2005). Ruangan ini menjadi faktor penting kerana pengguna PPM dalam kajian ini adalah terdiri daripada golongan bekerja (rujuk Jadual 1). Golongan tersebut merupakan golongan yang menghadapi limitasi masa dalam melengkapkan tugasan harian (Pigatto et al., 2017). Antara lokasi pilihan dengan kemudahan akses kepada wifi ialah premis perniagaan makanan segera seperti KFC, Mcdonald dan PizzaHut (Yeo et al., 2017).

Seterusnya kajian ini mendapati, walaupun kemudahan PPM yang secara dasarnya memungkinkan pengguna memilih mana-mana tempat makan, tetapi pengguna lebih cenderung memilih jarak lokasi yang dekat dengan mereka serta memanfaatkan kemudahan yang disediakan. Salah satu daripada elemen lokasi adalah ketersampaian yang mudah kepada pengguna (Timor \& Sipahi 2005; Hanaysha 2016). Jadi secara tidak langsung, elemen lokasi menjadi penting dalam penggunaan PPM malah pengurusan yang sistematik terhadap lokasi tersebut akan meningkatkan lagi pengguna (Dixon et al., 2009; He et al., 2019). Oleh itu, pihak bertanggungjawab haruslah membuat penelitian pengaruh lokasi premis perniagaan sebagai langkah meningkatkan penggunaan PPM. Antara langkah yang boleh diambil adalah dengan melaksanakan pengurusan lokasi yang bersifat menyeluruh iaitu berdekatan dengan kawasan tumpuan penduduk serta kemudahan akses kepada internet. 
Seterusnya, kajian ini melihat aspek faktor dalaman iaitu kualiti perkhidmatan yang ditawarkan yang menjadi faktor kecenderungan penggunaan PPM. Dapatan kajian ini menunjukkan bahawa komunikasi dengan pelanggan sangat perlu dititikberatkan oleh PPM ini. Hal ini disebabkan oleh hasil skor min bagi komunikasi dengan pelanggan iaitu 4.05 pada tahap tinggi dan diikuti oleh khidmat pelanggan iaitu 3.95, bagi skor min harga berpatutan iaitu 3.60 pada tahap sederhana dan juga skor min bagi caj penghantaran iaitu 3.47. Komunikasi yang sopan berkesan menarik pengguna untuk terus menggunakan perkhidmatan yang disediakan (Ilham, 2005). PPM ini seharusnya mengekalkan kualiti penyampaian komunikasi antara pengguna kerana mereka beranggapan membayar kepada perkhidmatan yang disediakan (Dholakia \& Zhao, 2010). Dapatan kajian ini diperkukuhkan lagi oleh kajian Soriano (2002) menjelaskan pengguna mempunyai alasan tersendiri mereka memilih tempat makan, salah satu alasan yang digunakan iaitu kualiti perkhidmatan yang ditawarkan oleh tempat makan tersebut. Kesan daripada faktorfaktor tersebut menyebabkan pengguna PPM semakin meluas sama ada menggunakan aplikasi yang disediakan seperti Foodpanda, Grab Food dan DeliverEat mahupun daripada premis perniagaan seperti KFC Delivery dan Mcd Delivery.

Penggunaan PPM juga disebabkan perubahan gaya hidup penduduk, analisis skor min dilakukan dengan menetapkan beberapa pengukuran. Antara pengukuran yang digunakan merangkumi teknologi (lokasi mudah akses-GPS), kemudahan internet, kemudahan telefon pintar dan aplikasi PPM yang mudah digunakan. Skor min yang pada tahap tertinggi adalah pengukuran aplikasi PPM mudah digunakan iaitu 4.61, diikuti oleh kemudahan telefon pintar iaitu 4.40, teknologi (lokasi mudah akses-GPS) dan kemudahan internet iaitu 3.93. Teknologi baru diperkenalkan seharusnya mudah difahami dan dipelajari dalam mempengaruhi pengguna terhadap teknologi tersebut, hal ini bertetetapan dengan kajian yang dijalankan oleh Davis et al., (1989) membincangkan bahawa teknologi yang mudah digunakan mampu mempengaruhi tingkah laku pengguna. Dapatan kajian ini menunjukkan bahawa aplikasi PPM yang mudah digunakan oleh responden dalam mendapatkan makanan dengan segera secara pesanan menggunakan PPM ini (Davis et al., 1989).

Seterusnya, faktor peningkatan kecenderungan penduduk terhadap PPM ini disebabkan penularan pandemik COVID-19 yang melanda dunia baru-baru ini. Bagi mengenalpasti kecenderungan penduduk terhadap PPM disebabkan faktor tersebut, kajian ini menganalisis menggunakan pengukuran PKP yang dilaksanakan, skor min menunjukkan bahawa pengukuran tersebut pada tahap yang tinggi iaitu 3.61. Sepanjang pelaksanaan PKP, kerajaan telah mengalakkan penduduk mengunakan perniagaan secara dalam talian bagi mengurangkan pergerakan fizikal penduduk ke suatu tempat (BERNAMA, 2020). Salah satu daripada perniagaan tersebut adalah PPM, penggunaan PPM telah menunjukkan peningkatan yang drastik disebabkan penularan pendemik ini. Peningkatan penggunaan PPM ini disebabkan penduduk bimbang dan tidak selesa ke kawasan orang ramai seperti tempat makan (Suhaimi Ab Rahman 2020). Oleh itu, PPM menjadi pilihan penduduk mendapatkan makanan kesukaan dengan segera tanpa perlu bergerak ke premis perniagaan tersebut.

Rentetan daripada keseluruhan perbincangan tersebut, terdapat empat faktor utama kecenderungan penduduk terhadap PPM iaitu faktor lokasi, kualiti perkhidmatan yang ditawarkan, perubahan gaya hidup dan penularan pandemik COVID-19. Hasil analisis daripada faktor tersebut, pengukuran pada tahap tinggi diwakili oleh ruangan tempat letak kenderaan, komunikasi dengan pelanggan, aplikasi PPM mudah digunakan dan PKP yang dilaksanakan. Kesemua pengukuran tersebut menjadi penyebab kepada kecenderungan pengguna terhadap PPM malah PPM ini menunjukkan peningkatan penggunaannya dalam kalangan penduduk termasuklah di kawasan luar 
bandar. Oleh itu, penerimaan PPM ini menjelaskan bahawa kehidupan penduduk mula bergantung kepada ICT akibat kekangan-kekangan yang dihadapi.

\section{Perubahan gaya hidup}

Selain mengenalpasti faktor kecenderungan penduduk terhadap PPM, kajian ini juga mengkaji perubahanan gaya hidup yang berlaku dalam kalangan penduduk di Pulau Pinang. Bagi memudahkan perbincangan dalam bahagian ini, kajian ini telah menganalisis kekerapan penggunaan PPM yang menjadi pilihan kepada penduduk. Terdapat empat jenis perkhidmatan PPM yang seringkali digunakan oleh penduduk di Pulau Pinang. Antara perkhidmatan tersebut adalah Foodpanda, Grab Food, KFC Delivery dan Mcd Delivery (rujuk Jadual 3).

Berdasarkan kepada Jadual 3 menunjukkan majoriti responden kajian ini menggunakan perkhidmatan Foodpanda iaitu sebanyak 90.0 peratus. Selain daripada perkhidmatan Foodpanda, rata-rata responden kajian ini turut menggunakan Grab Food sebagai perkhidmatan pilihan dalam membuat pesanan mendapatkan makanan iaitu sebanyak 78.1 peratus. Responden juga menggunakan perkhidmatan yang disediakan oleh premis perniagaan seperti $K F C$ Delivery dan Mcd Delivery menunjukkan 56.4 peratus dan 59.1 peratus. Manakala, bagi perkhidmatan lain yang digunakan oleh responden seperti DeliverEat, Domino's Delivery, Pizza Hut Delivery dan penggunaan laman sesawang menunjukkan 47.3 peratus.

Perbandingan kekerapan PPM yang digunakan dalam kajian ini menunjukkan bahawa penduduk di Pulau Pinang mula bergantung kepada kemajuan teknologi bagi menjalani kehidupan seharian. Dapatan ini memberikan maklumat penting iaitu pergerakan secara luar talian (fizikal) beralih kepada pergerakan secara dalam talian (maya) menggunakan PPM ini (Güneralp et al., 2012; Seto et al, 2012; Konrad, \& Wittowsky 2018; Daniel et al., 2018). Selain daripada perubahan pergerakan secara dalam talian, dapatan kajian Jadual 3 menunjukkan responden menerima penggunaan PPM dalam rutin kehidupan mereka. Penerimaan ini menunjukkan perubahan ke arah gaya hidup responden yang lebih digital (Carsten et. al., 2016).

Jadual 3. Jenis PPM yang digunakan di Pulau Pinang

\begin{tabular}{lcc}
\hline Jenis PPM & Kekerapan & Peratusan (\%) \\
\hline Foodpanda & $99 / 110$ & 90.0 \\
Grab Food & $86 / 110$ & 78.1 \\
KFC Delivery & $62 / 110$ & 56.4 \\
Mcd Delivery & $65 / 110$ & 59.1 \\
Lain-lain & $52 / 110$ & 47.3 \\
\hline
\end{tabular}

Sumber: Kajian lapangan, 2020

Perniagaan PPM yang semakin berkembang menunjukkan penduduk menerima PPM bagi mendapatkan makanan dengan segera dalam rutin kehidupan seharian. Dapatan kajian ini membolehkan perancangan terhadap PPM secara efektif dan holistik dalam meningkatkan penggunaan PPM ini. Dalam konteks kajian ini, pengukuran lokasi seharusnya diteliti bagi penyediaan platform infrastruktur ICT iaitu sokongan jalur lebar oleh pihak berkuasa tempatan dalam meningkatkan penggunaan PPM. Melalui maklumat kajian ini turut membolehkan pihak agensi PPM menganalisis keadaan semasa mutu dan kualiti perkhidmatan yang diberikan. Hal ini membolehkan pihak agensi PPM mengetahui usaha yang perlu dilakukan supaya PPM yang ditawarkan menjadi pilihan pengguna. 
Antara usaha yang boleh dilakukan seperti memberikan latihan komunikasi kepada agen penghantaran PPM. Salah satu faktor diteliti menerusi kajian ini adalah perubahan gaya hidup penduduk ke arah menggunakan teknologi dalam kehidupan seharian menggunakan PPM. Peningkatan penggunaan PPM ini selaras dengan sasaran evolusi 4.0 iaitu penggunaan internet dalam kehidupan seharian, segala usaha pihak perancang dasar dan polisi perlulah ditingkatkan dari semasa ke semasa dalam usaha meningkatkan pengguna PPM ini. Kajian ini juga menfokuskan kepada faktor PKP yang dilaksanakan semasa penularan COVID-19, pihak berkuasa tempatan seharusnya mengawal selia dengan baik kerana perniagaan PPM ini berpotensi menjadi satu industri meningkatkan pendapatan negara.

\section{Kesimpulan}

Perkembangan perbandaran yang pesat berlaku seiring dengan kemajuan teknologi menyebabkan pelbagai platform yang dicipta untuk memudahkan penduduk mendapatkan makanan dengan segera. Salah satu daripada platform itu adalah PPM. Bagi konteks pengguna PPM yang berada di bandar menunjukkan bahawa faktor lokasi seperti ruangan tempat letak kenderaan amat penting dalam mempengaruhi penggunaan PPM. Manakala, faktor agensi PPM penting kerana ianya secara tidak langsung memberikan kesan kepada pemilihan PPM yang melibatkan kualiti disediakan. Hasil daripada faktor-faktor tersebut menyebabkan PPM semakin digemari kerana memudahkan urusan mendapatkan makanan dengan segera, cepat dan menjimatkan masa. Oleh itu, penggunaan PPM ini adalah penting jika dikawal selia dengan baik agar ianya boleh menjadi satu industri yang membantu meningkatkan pendapatan negara.

\section{Penghargaan}

Penulis ingin mengucapkan ribuaan terima kasih kepada responden yang sangup terlibat dengan kajian ini. Penghargaan kepada Kementerian Pengajian Tinggi yang membiayai penyelidikan ini melalui Skim Geran Penyelidikan Fundamental (FRGS) No. 203/PHUMANITI/6711709.

\section{Rujukan}

Aladağ, C. (2019). Opinions of geography and social sciences student-teachers on theconcepts of urbanization and urbanizing. Education and Urban Society, 51(3), 351-373.

Annaraud, K., \& Berezina, K. (2020). Predicting satisfaction and intentions to use online food delivery: What really makes a difference? Journal of Foodservice Business Research, 23(4), 305-323.

BERNAMA (2020). Permintaan penghantaran makanan melonjak 30 peratus. Retrieved from https://www.sinarharian.com.my/article/74393/BERITA/Nasional/Permintaanpenghantar an-makanan-melonjak-30-peratus

Carsten H, Alexander R, Thomas S, \& Martin W. (2016). The changing market for food delivery. Retrieved from https://www.mckinsey.com/industries/high-tech/ourinsights/the changing market-for-food-delivery

Chai, L. T., \& Yat, D. N. C. (2019) Online food delivery services: Making food delivery thenew 
normal. Journal of Marketing Advances and Practices, 1(1), 64-79.

Cho, M., Bonn, M. A., \& Li, J. J. (2019). Differences in perceptions about food delivery apps between single-person and multi-person households. International Journal of Hospitality Management, 77, 108-116.

Daniel, E., Di Domenico, M., \& Nunan, D. (2018). Virtual mobility and the lonely cloud:Theorizing the mobility-isolation paradox for self-employed knowledge-workers in the online home-based business context. Journal of Management Studies, 55(1), 174-203.

Davis, F. D. (1989). Perceived usefulness, perceived ease of use, and user acceptance of information technology. MIS quarterly, 319-340.

Davis, F. D., Bagozzi, R. P., \& Warshaw, P. R. (1989). User acceptance of computer technology: a comparison of two theoretical models. Management science, 35(8), 982-1003.

Dholakia, R. R., \& Zhao, M. (2010). Effects of online store attributes on customer satisfaction and repurchase intentions. International Journal of Retail \& Distribution Management, 38(7), 482-496

Dixon, M., Kimes, S. E., \& Verma, R. (2009). Customer preferences for restaurant technology innovations. Cornell Hospitality Report, 9(7), 6-16.

Flavián, C., \& Guinalíu, M. (2006). Consumer trust, perceived security and privacy policy. Industrial Management \& Data Systems, 106(5), 601-620

Güneralp, B., Reilly, M. K., \& Seto, K. C. (2012). Capturing multiscalar feedbacks in urban land change: a coupled system dynamics spatial logistic approach. Environment and Planning B: Planning and Design, 39(5), 858-879.

Hanaysha, J. (2016). Restaurant location and price fairness as key determinants of brand equity: A study on fast food restaurant industry. Business and Economic research, 6(1), 310-323.

He, Z., Han, G., Cheng, T. C. E., Fan, B., \& Dong, J. (2019). Evolutionary food quality and location strategies for restaurants in competitive online-to-offline food ordering and delivery markets: An agent-based approach. International Journal of Production Economics, 215, 61-72.

Ilham, R. (2018). Improve quality of e-loyalty in online food delivery services: A case of Indonesia. Journal of Theoretical and Applied Information Technology, 96(15), 47604769.

Jabatan Perangkaan Malaysia. (2018) Anggaran Penduduk Semasa Malaysia 2018. Jabatan Perangkaan Malaysia. Retrieved from https://www.dosm.gov.my/v1/index.php?r= column/pdfPrev\&id=Vjc3dFd5cXhNYTZtb VhS0lEWEpudz09

Jabatan Perangkaan Malaysia. (2020) Anggaran Penduduk Semasa Malaysia 2020. Jabatan Perangkaan Malaysia. Malaysia. Retrieved from https://www.permohonan.my/jumlah penduduk-malaysia-terkini/\#statistik-terkini-jumlah-penduduk-malaysia-2020

Jiang, L. A., Yang, Z., \& Jun, M. (2013). Measuring consumer perceptions of online shopping convenience. Journal of Service Management, 24(2), 191-214.

Keeble, M., Adams, J., Sacks, G., Vanderlee, L., White, C. M., Hammond, D., \& Burgoine, T. (2020). Use of online food delivery services to order food prepared away-from-home and associated sociodemographic characteristics: A cross-sectional, multi-country analysis. International journal of environmental research and public health, 17(14), 5190.

Kimes, S. E. (2011). The current state of online food ordering in the US restaurant industry. Cornell Hospitality Report, 11(17), 6-18.

Konrad, K., \& Wittowsky, D. (2018). Virtual mobility and travel behavior of young people Connections of two dimensions of mobility. Research in Transportation Economics, 68, 11-17. 
Ku Intan Safinas, K, M., Nadiah, A, Z., \& Haslina, C, N. (2015). Assessing on accessibility and restaurant attributes towards customer retention. Journal of Applied Environmental and Biological Sciences, 5(6S) 9-13.

Laddha, D. (2019). Impact of consumer demographics on usage of online food services. IUJ Journal of Management, 7(2), 1-5.

Ledimo, O., \& Martins, N. (2015). The perceptions and nature of service delivery among government employees: An Exploratory study. Journal of Governance and Regulation, 4(4), 575-580.

Li, C., Mirosa, M., \& Bremer, P. (2020). Review of online food delivery platforms and their impacts on sustainability. Sustainability, 12(14), 5528.

Liza Mohtar, \& Nurul Riduan Nor Ashana. (2020). Jualan dalam talian naik berganda. Sinar Online 25 Mac 2f020. Retrieved from https://www.sinarharian.com.my/article/ 75443/KHAS/Koronavirus/Jualan-dalam-talian-naik-berganda

Macrotrends. (2021). Malaysian Population 1950-2021. Retrieved from https://www.macrotrends.net/countries/ MYS/malaysia/population

Nicola, M., Alsafi, Z., Sohrabi, C., Kerwan, A., Al-Jabir, A., Iosifidis, C., \& Agha, R. (2020). The socio-economic implications of the coronavirus pandemic (COVID-19): A review. International journal of surgery, 78, 185.

Nabila, M., Purwandari, B., Nazief, B. A., Chalid, D. A., Wibowo, S. S., \& Solichah, I. (2018). Financial Technology Acceptance Factors of Electronic Wallet and Digital Cash in Indonesia. In 2018 International Conference on Information Technology Systems and Innovation (ICITSI) (pp. 284-289). IEEE

Nazurah Ngah, Mohd Nasaruddin Parzi, \& Luqman Arif Abdul Karim. (2017). Penembusan jalur lebar 81.8 peratus. Retrieved from https://www.bharian.com.my/berita/nasional/2017/11/ 353046/penembusan-jalur-lebar-818-peratus

Parsa, H. G., Gregory, A., \& Terry, M. (2011). Why do restaurants fail? Part III: An analysis of macro and micro factors. Dick Pope Sr. Institute Publication, 1-20.

Pigatto, G., Machado, J. G. D. C. F., dos Santos Negreti, A., \& Machado, L. M. (2017). Have you chosen your request? Analysis of online food delivery companies in Brazil. British Food Journal, 119(3), 639-657.

Rancangan Struktur Negeri Pulau Pinang 2030. (2018). Memakmurkan Pulau Pinang sebagai sebuah negeri pintar, harmoni, dan bertaraf antarabangsa. Retrieved from http://epublisiti.townplan.gov.my/turun/rsn_pulaupinang2030/rsnpp2030.pdf

Rostam, K., Rosul, M., Er, A. C., Nor, A. R. M., Sakawi, Z., \& Hashim, N. M. (2017). Pembandaran dan rebakan bandar di pinggir Wilayah Metropolitan Klang-Langat. Geografia-Malaysian Journal of Society and Space, 6(2), 37-50.

Sakaran, S. S., Noor, H. M., \& Rosmiza, M. Z. (2020). Ketersampaian penduduk terhadap perkhidmatan pengangkutan awam di Bandaraya Kota Kinabalu, Sabah. GeografiaMalaysian Journal of Society and Space, 16(1), 168-181.

See-Kwong, G., Soo-Ryue, N., Shiun-Yi, W., \& Lily, C. (2017). Outsourcing to online food delivery services: Perspective of F\&B business owners. The Journal of Internet Banking and Commerce, 22(2), 1-18.

Seto, K. C., Reenberg, A., Boone, C. G., Fragkias, M., Haase, D., Langanke, T., \& Simon, D. (2012). Urban land teleconnections and sustainability. Proceedings of the National Academy of Sciences, 109(20), 7687-7692. 
Shih, H. P. (2004). An empirical study on predicting user acceptance of e-shopping on the Web. Information \& management, 41(3), 351-368.

Soriano, D. R. (2002). Customers' expectations factors in restaurants: The situation in Spain. International Journal of Quality \& Reliability Management, 19(8/9), 1055-1067. https://doi.org/10.1108/02656710210438122.

Statista.com (2020). Online Food Delivery, Malaysia. Retrieved from https://www.statista.com/outlook/374/122/online-food-delivery/malaysia

Suan, Y. (2003). Computer aplication in educational research. School of Education Studies. University Science Malaysia

Suhaimi Ab Rahman (2020) Industri penghantaran makanan halal perlu kawalan kerajaan. Bernama Online 1 Mei 2020. Retrieved from https://www.bernama.com/bm/ tintaminda/news.php?id=1837382

Suruhanjaya Komunikasi dan Multimedia. (2020) Internet User Survey 2020. Retrieved from https://www.mcmc.gov.my/skmmgovmy/media/General/pdf/IUS-2020-Infographic.pdf

Tan, D. (2019) Food delivery firm delivers on growth. The Star online 11 Nov 2019. Retrieved from http://www.thestar.com.my/business/smebiz/2019/11/11/food-delivery-firm-on growth

Taylor, B. D., \& Fink, C. N. (2003). The factors influencing transit ridership: A review and analysis of the ridership literature. UC Berkeley: University of California Transportation Center. Retrieved from https://escholarship.org/uc/item/3xk9j8m2.

Timor, M., \& Sipahi, S. (2005). Fast-food restaurant site selection factor evaluation by the analytic hierarchy process. The Business Review Cambridge, 4(1), 161-167.

Tzeng, G. H., Teng, M. H., Chen, J. J., \& Opricovic, S. (2002). Multicriteria selection for restaurant location in Taipei. International Journal of Hospitality Management, 21(2), 171187.

United Nation. (2008). An Overview Of Urbanization, Internal Migration, Population Distribution And Development In The World. Retrieved from https://sustainabledevelopment.un.org/content/documents/2529P01_UNPopDiv.pdf

United Nation. (2019). World Populations Prospects 2019, Population Division: Highlights. https://population.un.org/wpp/Publications/Files/WPP2019_Highlights.pdf.

Yeo, V. C. S., Goh, S. K., \& Rezaei, S. (2017). Consumer experiences, attitude and behavioral intention toward online food delivery (OFD) services. Journal of Retailing and Consumer Services, 35, 150-162.

Yusof, N., Lazim, N. M., \& Dawood, S. R. S. (2013). Pelaburan Asing dan Pencapaian Pembangunan Seimbang di NCER: Satu Ulasan Kritis. Akademika, 83(2 \& 3).

Zulkarnain, K., Ahasanul, H., \& Selim, A. (2015). Key success factors of online food ordering services: An empirical study. Malaysian institute of Management, 50(2), 19-36. 